\title{
Silvopastoral systems drive the nitrogen-cycling bacterial community in soil
}

\author{
Sistema silvipastoril influencia na comunidade de bactérias do solo \\ relacionadas ao ciclo do nitrogênio
}

\author{
Felipe Martins do Rêgo Barros ${ }^{1}$, Giselle Gomes Monteiro Fracetto ${ }^{1 *}$, Felipe José Cury Fracetto ${ }^{1}$, \\ José Petrônio Mendes Júnior ${ }^{1}$, Victor Lucas Vieira Prudêncio de Araújo ${ }^{1}$, Mario Andrade Lira Junior ${ }^{1}$
}

${ }^{1}$ Universidade Federal Rural de Pernambuco/UFRPE, Departamento de Agronomia, Recife, PE, Brasil

*Corresponding author: giselle.fracetto@ufrpe.br

Received in April 18, 2018 and approved in June 13, 2018

\begin{abstract}
Intercropping tree legumes with forage grasses in a silvopastoral system can avoid pasture degradation benefiting the soil. In such a system, nitrogen $(\mathrm{N})$ is supplied by symbiosis between legumes and bacteria. However, the pasture quality determines the action of free-living nitrogen-fixing bacteria, which possess nifH genes, which encode nitrogenase enzyme. Ammonium-oxidizing bacteria (AOB), involved in the nitrification step, can be evaluated by specific regions of the $16 \mathrm{~S}$ rRNA corresponding to AOB. Thus, we investigated the influence of the introduction of tree legumes into a silvopastoral system on the community structure and abundance of total bacteria, diazotrophic bacteria and ammonium-oxidizing bacteria by DGGE (denaturing gradient gel electrophoresis) and real-time qPCR (quantitative PCR). The experiment involved nine plots of one hectare each, planted with sabia (Mimosa caesalpinifolia), a Gliricidia species (Gliricidia sepium), and a Brachiaria species (Brachiaria decumbens) in a randomized block design, forming three treatments: I-Brachiaria intercropped with sabia; II-Brachiaria intercropped with Gliricidia and III-Brachiaria only, with three replicates. The structures of the total bacterial and ammoniumoxidizing bacterial communities were influenced by tree legume introduction, possibly through modification of the soil chemical attributes. The copy numbers of total bacteria, ammonium-oxidizing bacteria and diazotrophic bacteria were higher in soils planted with legumes, which provided better conditions for microbial growth compared to planting with the Brachiaria species alone. Silvopastoral management with tree legumes improves the biological quality of soil, favouring the bacterial community linked to $\mathrm{N}$-cycling.
\end{abstract}

Index terms: Tree legumes; Brachiaria; 16 rRNA; AOB; nifH.

\section{RESUMO}

O consórcio de leguminosas arbóreas com gramíneas forrageiras em sistema silvipastoril pode evitar a degradação das pastagens e recuperá-las. Neste sistema, o fornecimento de nitrogênio (N) ocorre através da simbiose entre leguminosas e bactérias. No entanto, a qualidade das pastagens permite a ação de bactérias diazotróficas de vida livre, que possuem o gene nifH que codifica a enzima nitrogenase. Além disso, na etapa da nitrificação, as bactérias amônio oxidantes (AOB) são avaliadas por regiões específicas do 16S rRNA de AOB. Assim, investigamos a influência da introdução das leguminosas arbóreas no sistema silvipastoril na estrutura da comunidade, na diversidade e na abundância de bactérias totais, bactérias diazotróficas e bactérias amônio oxidantes por DGGE (Eletroforese em Gel com Gradiente Desnaturante) e qPCR (PCR quantitativa em tempo real). O experimento teve nove parcelas de um hectare com Sabiá (Mimosa caesalpinifolia), Gliricídia (Gliricidia sepium) e Braquiária solteira (Brachiaria decumbens), em delineamento em blocos ao acaso com três tratamentos: I-Braquiária em consórcio com Sabiá; II-Braquiária em consórcio com Gliricídia e III - Braquiária solteira, com três repetições. A estrutura das comunidades de bactérias totais e bactérias amônio oxidantes foi influenciada pela introdução das leguminosas arbóreas, possivelmente por meio da modificação dos atributos químicos do solo. Bactérias totais, bactérias amônio oxidantes e bactérias diazotróficas foram mais abundantes nos solos sob leguminosas, que proporcionaram melhores condições para o crescimento microbiano quando comparado à braquiária solteira. O manejo silvipastoril com leguminosas arbóreas melhora a qualidade biológica do solo, favorecendo a comunidade bacteriana ligada ao ciclo do $\mathrm{N}$.

Termos para indexação: Leguminosas arbóreas; brachiaria; 16 rRNA; AOB; nifH.

\section{INTRODUCTION}

Intercropping tree legumes (Fabaceae family) with forage grasses in a silvopastoral system can increase the nutrient, mainly nitrogen, content in the soil through biological fixation by legume rhizobia (Ashworth; West,
2015; Xavier et al., 2011). This management practice has been successfully used in the recovery and maintenance of degraded pastures, with known impacts on the soil chemistry and quality (Apolinário et al., 2016; Silva et al., 2013), but no information has been reported about the influence on soil microbial communities. 
Soil microorganisms are sensitive to environmental changes and are good indicators of soil quality (Paz-Ferreiro; $\mathrm{Fu}, 2013)$. The floristic composition and management practices adopted in agriculture are among the factors responsible for variations in the soil bacterial community (Ding et al., 2013; Jesus et al., 2009). The effect of plants has been observed, especially in the rhizosphere, where there is a direct influence of root exudates (Sugiyama et al., 2014). In addition to plant cover, the soil bacterial community is influenced by physicochemical soil characteristics (Kuramae et al., 2012; Qu et al., 2016).

The nitrogen transformations in the soil are dependent on oxidation reactions mediated by microorganisms. Biological nitrogen fixation (BNF) and nitrification (stages of $\mathrm{N}$ cycling) are directly linked to the action of bacteria and archaea (Canfield; Glazer; Falkowski, 2010). In BNF, atmospheric nitrogen $\left(\mathrm{N}_{2}\right)$ is converted to ammonium $\left(\mathrm{NH}^{+}\right)$in root nodules formed by legume-rhizobia symbiosis (Ashworth et al., 2015) and by the free-living diazotrophic bacteria present in the soil (Wurzburger et al., 2012). N fixation is due to the performance of the enzymatic nitrogenase complex, which catalyses the reduction of dinitrogen $\left(\mathrm{N}_{2}\right)$ to ammonia $\left(\mathrm{NH}_{3}\right.$ ), which is protonated to form $\mathrm{NH}_{4}^{+}$(Ipata; Pesi, 2015; Keuter; Veldkamp; Corre, 2014).

In nitrification, specific groups of bacteria sequentially oxidize $\mathrm{NH}_{4}^{+}$to nitrate $\left(\mathrm{NO}_{3}^{-}\right)$. Initially, $\mathrm{NH}_{4}^{+}$is oxidized to hydroxylamine by organisms containing the monooxygenase ammonium enzyme. Subsequently, hydroxylamine is oxidized to nitrite $\left(\mathrm{NO}_{2}^{-}\right)$by the enzyme hydroxylamine oxide reductase. $\mathrm{NO}_{2}^{-}$is oxidized to $\mathrm{NO}_{3}^{-}$by the enzyme nitrite oxido reductase (Canfield; Glazer; Falkowski, 2010). In anaerobic conditions, $\mathrm{NO}_{3}^{-}$can be used as the final electron acceptor by facultative anaerobic bacteria during denitrification, producing $\mathrm{N}_{2}$ (Fracetto, et al., 2017).

In natural ecosystems, soil microbial communities are responsible for metabolic processes that sustain the base of the food chain through the supply of nutrients (Lima-Perim et al., 2016). Diazotrophic bacteria are the main responsible for the $\mathrm{N}$ supply in tropical forests, dominating the bacteria that are symbiotic with legumes and occurring as free-living bacteria in the soil and in the litter. On the other hand, ammonium-oxidizing bacteria (AOB) play an important role in the regulation of $\mathrm{N}$ availability in forests, which occurs through $\mathrm{NO}_{3}$ leaching and $\mathrm{N}_{2} \mathrm{O}$ production (directly and indirectly) through nitrification (Pajares; Bohannan, 2016).

In agroecosystems, microbial communities can also be used to promote plant growth (Weidner et al., 2015). Through legume-rhizobia symbiosis, intercropping tree legumes with pastures can fix up to $108 \mathrm{~kg} \mathrm{ha}^{-1}$ of $\mathrm{N}$ per year (Apolinário et al., 2015). In irrigated streams, the symbiosis between Azolla and cyanobacteria can add approximately $30 \mathrm{~kg} \mathrm{ha}^{-1} \mathrm{~N}$ per year (Herridge; Peoples; Boddey, 2008). Studies have shown that diazotrophic associative endophytic bacteria may contribute more than $50 \%$ of the $\mathrm{N}$ requirement for sugarcane through biological nitrogen fixation (Urquiaga et al., 2012; Yeoh et al., 2016).

Molecular techniques have been used to evaluate the structure, diversity and abundance of soil bacterial communities, avoiding the limitations of cultivationdependent techniques (Hill et al., 2000; Levy-Booth; Prescott; Grayston, 2004). The 16S rRNA gene has been widely used for the study of the total bacteria present in the soil because this gene has variable and highly conserved regions (Patwardhan; Ray; Roy, 2014).

Diazotrophic bacteria can be evaluated through the nif genes responsible for encoding the subunits of the nitrogenase complex (Gaby; Buckley, 2012). In addition, ammonium-oxidizing bacteria can be evaluated using specific regions of the AOB $16 \mathrm{~S}$ rRNA gene belonging to the $\beta$-proteobacterial subdivision as a molecular marker (Dias et al., 2012; Kowalchuk et al., 1997; Tourna et al., 2008).

We hypothesized that silvopastoral systems drive the soil community of bacteria participating in nitrogen cycling. Thus, we investigated the structure and abundance of the total bacterial community, nitrogen-fixing bacteria and ammonium-oxidizing bacteria in the soil by DGGE (denaturing gradient gel electrophoresis) and qPCR (realtime quantitative PCR).

\section{MATERIAL AND METHODS}

The study area is located at the experimental station of Instituto Agronômico de Pernambuco (IPA) in Itambé city, Pernambuco state, Brazil $\left(07^{\circ} 25^{\prime}, 35^{\circ} 06^{\prime} \mathrm{W}, 190 \mathrm{~m}\right.$ altitude). The climate is hot and humid, classified as AS (classification by Köppen), with an average rainfall of $1.200 \mathrm{~mm}$ year ${ }^{-1}$, an annual average temperature of $24{ }^{\circ} \mathrm{C}$, a relative humidity of $80 \%$, and a higher occurrence of rainfall from April to July (Instituto Agronômico de Pernambuco - IPA, 1994, Companhia Pernambucana Recursos Hídricos - PRH, 2003).

The experiment has been ongoing since 2011, with nine plots of one hectare each, planted with tree legumes Sabia (Mimosa caesalpinifolia) and Gliricidia (Gliricidia sepium) and a single species of Brachiaria (Brachiaria decumbens) without nitrogen fertilization. The legume planting consisted of double rows with a spacing of $15 \mathrm{mx}$ $1 \mathrm{~m} \times 0.5 \mathrm{~m}$ and the presence of Brachiaria in the legume bands. The experimental design was a randomized complete 
block with three treatments: I-Brachiaria intercropped with Sabia $(\mathrm{B}+\mathrm{S})$; II-Brachiaria intercropped with Gliricidia $(B+G)$ and III-Brachiaria alone (B), with three replicates.

In the intercropped plots, soil samples were collected between the single rows of legumes in the double row at a depth of $0.20 \mathrm{~m}$. In the Brachiaria-only plots, three soil samples were randomly collected to serve as a single composite sample at the same depth. Samples were stored in sterile plastic bags and were frozen at $-20{ }^{\circ} \mathrm{C}$. A portion of the samples was air-dried, stripped and sieved through a $2 \mathrm{~mm}$ mesh screen to determine the physical and chemical attributes (Table 1).

The DNA was extracted from $0.4 \mathrm{~g}$ of soil using the DNeasy PowerSoil Kit (QIAGEN Laboratories, Carlsbad, CA, USA) following the manufacturer's instructions. The integrity of the obtained DNA was verified by $1 \%$ agarose gel electrophoresis at $100 \mathrm{~V}$ for 30 minutes in $0.5 \mathrm{x}$ TBE buffer (Tris, Borate, EDTA) added to the SYBR ${ }^{\circledR}$ Gold dye (Invitrogen, Breda, The Netherlands).
The 16S rRNA gene fragment was used for PCRDGGE analysis as the molecular marker, using 341f-GC and 518R primers for amplification (Muyzer; Dewaal; Uitterlinden, 1993). Nested PCR was used for ammoniumoxidizing bacteria (AOB) and diazotrophic bacteria (nifH) analysis. The ammonium-oxidizing bacterial communities were assessed with a specific region of the 16S rRNA gene exclusive to $\mathrm{AOB}$, belonging to the $\beta$-proteobacterial subdivision, amplified with CTO189fA/CTO189fB, CTO189fC and CTO 654r primers. These primers amplify regions corresponding to the genera Nitrosomonas and Nitrosospira, which are the main oxidizers of ammonium in acidic soils (Kowalchuk; Stephen, 2001). The resulting amplicons were used as templates in a second PCR reaction with 341f-GC and 518R primers. Each reaction followed the procedure in Kowalchuk et al. (1997). To amplify the nifH gene, FGPH19 and PolR primers were used in the initial amplification, followed by POLF-GC and AQER primers in the second reaction. The conditions and reaction

Table 1: Primers and cycling conditions used to amplify the target genes.

\begin{tabular}{|c|c|c|}
\hline Primers PCR-DGGE & Primer sequence $\left(5^{\prime}-3^{\prime}\right)$ & Thermal cycling conditions \\
\hline \multicolumn{3}{|c|}{ Total bacteria (16S rRNA) } \\
\hline $\begin{array}{l}341 \mathrm{f}-\mathrm{GC}^{1} \\
518 \mathrm{r} 1\end{array}$ & $\begin{array}{c}\text { CGCGGCGGGCGGGGCGGGGGCACGGGGGG } \\
\text { ATTACCGCGGCTGCTGG }\end{array}$ & $\begin{array}{c}95^{\circ} \mathrm{C} 10 \mathrm{~min}, 1 \mathrm{cycle} ; 95^{\circ} \mathrm{C} 1 \mathrm{~min}, 57^{\circ} \mathrm{C} 1 \\
\text { min, } 72{ }^{\circ} \mathrm{C} 3 \text { min, } 30 \text { cycles; } 72^{\circ} \mathrm{C} 10 \mathrm{~min}, 1 \\
\text { cycle. }\end{array}$ \\
\hline $\begin{array}{l}\text { CTO189fA/CTO189fB } \\
\text { CTO189fC } \\
\text { R1 }^{3}\end{array}$ & $\begin{array}{l}\text { GGAGRAAAGCAGGGGATCG } \\
\text { GGAGGAAAGTAGGGGATCG } \\
\text { CGTCCTCTCAGACCARCTACTG }\end{array}$ & $\begin{array}{l}95^{\circ} \mathrm{C} 3 \mathrm{~min}, 1 \text { cycle; } 95^{\circ} \mathrm{C} 30 \mathrm{~s}, 57^{\circ} \mathrm{C} 1 \mathrm{~min}, \\
68^{\circ} \mathrm{C} 45 \mathrm{~s}, 35 \text { cycles; } 68^{\circ} \mathrm{C} 5 \mathrm{~min}, 1 \text { cycle. }\end{array}$ \\
\hline \multicolumn{3}{|c|}{ Diazotrophic (nifH) } \\
\hline $\begin{array}{l}\mathrm{FGPH}_{19}^{4} \\
\mathrm{PolR}^{5}\end{array}$ & $\begin{array}{l}\text { TACGGCAARGGTGGNATH } \\
\text { ATSGCCATCATYTCRCCG }\end{array}$ & $\begin{array}{l}95^{\circ} \mathrm{C} 5 \mathrm{~min}, 1 \text { cycle; } 95^{\circ} \mathrm{C} 1 \mathrm{~min}, 55^{\circ} \mathrm{C} 1 \mathrm{~min}, \\
72^{\circ} \mathrm{C} 2 \mathrm{~min}, 30 \text { cycles; } 72^{\circ} \mathrm{C} 10 \mathrm{~min}, 1 \text { cycle. }\end{array}$ \\
\hline PolF-GC ${ }^{5}$ & $\begin{array}{l}\text { CGCCCGCCGCGCCCCGCGCCCGGCCCGCCG } \\
\text { CCCCCGCCCCTCCGAYCCSAARGCBGACTC }\end{array}$ & $\begin{array}{l}94^{\circ} \mathrm{C} 5 \mathrm{~min}, 1 \text { cycle; } 95^{\circ} \mathrm{C} 1 \mathrm{~min}, 48^{\circ} \mathrm{C} 1 \mathrm{~min}, \\
72^{\circ} \mathrm{C} 2 \mathrm{~min}, 30 \text { cycles; } 72^{\circ} \mathrm{C} 10 \mathrm{~min}, 1 \text { cycle. }\end{array}$ \\
\hline $\mathrm{AQER}^{5}$ & ACTATGTAGATYTCCTG & \\
\hline Primers qPCR & Primer sequence $\left(5^{\prime}-3^{\prime}\right)$ & Thermal cycling conditions \\
\hline \multicolumn{3}{|c|}{ Bacteria (16S rRNA) } \\
\hline $\begin{array}{l}341 f^{1} \\
518 r^{1}\end{array}$ & $\begin{array}{l}\text { CCTACGGGAGGCAGCAG } \\
\text { ATTACCGCGGCTGCTGG }\end{array}$ & $\begin{array}{c}95^{\circ} \mathrm{C} 5 \text { min, } 1 \text { cycle; } 95^{\circ} \mathrm{C} 10 \mathrm{~s}, 60^{\circ} \mathrm{C} 10 \mathrm{~s}, \\
72^{\circ} \mathrm{C} 30 \mathrm{~s}, 40 \text { cycles. }\end{array}$ \\
\hline \multicolumn{3}{|c|}{ AOB (16S rRNA) } \\
\hline $\begin{array}{l}\text { CTO189fA/CTO189fB } \\
\text { CTO189fC }^{2} \\
\text { R1 }^{3}\end{array}$ & $\begin{array}{l}\text { GGAGRAAAGCAGGGGATCG } \\
\text { GGAGGAAAGTAGGGGATCG } \\
\text { CGTCCTCTCAGACCARCTACTG }\end{array}$ & $\begin{array}{l}95^{\circ} \mathrm{C} 3 \text { min, } 1 \text { cycle; } 95^{\circ} \mathrm{C} 30 \mathrm{~s}, 58^{\circ} \mathrm{C} 1 \mathrm{~min}, \\
68^{\circ} \mathrm{C} 45 \mathrm{~s}, 35 \text { cycles; } 68^{\circ} \mathrm{C} 5 \text { min, } 1 \text { cycle. }\end{array}$ \\
\hline \multicolumn{3}{|c|}{$\mathrm{N}$ fixing bacteria (nifH) } \\
\hline $\begin{array}{l}\mathrm{FGPH}_{19} 9^{4} \\
\mathrm{PolR}^{5}\end{array}$ & $\begin{array}{l}\text { TACGGCAARGGTGGNATH } \\
\text { ATSGCCATCATYTCRCCG }\end{array}$ & $\begin{array}{l}95^{\circ} \mathrm{C} 5 \mathrm{~min}, 1 \text { cycle; } 94^{\circ} \mathrm{C} 1 \mathrm{~min}, 57^{\circ} \mathrm{C} 45 \mathrm{~s} \text {, } \\
72^{\circ} \mathrm{C} 1 \mathrm{~min}, 30 \text { cycles; } 72^{\circ} \mathrm{C} 7 \mathrm{~min}, 1 \text { cycle. }\end{array}$ \\
\hline
\end{tabular}

${ }^{1}$ Muyzer et al. (1993); ${ }^{2}$ Kowalchuk et al. (1997); ${ }^{3}$ Hermansson and Lindgren (2001); ${ }^{4}$ Simonet et al. (1991); ${ }^{5}$ Poly et al. (2001). 
concentrations followed the methodologies of Simonet et al. (1991) and Poly, Monrozier and Bally (2001).

The soil management conditions of the present study (non-fertilization and oxygen availability) did not justify other analyses related to denitrification.

PCR products were checked on a $1 \%$ agarose gel. DGGE profiles were generated using a DCode vertical electrophoresis system (Bio-Rad ${ }^{\circledR}$-California-EUA) using $8 \%(\mathrm{w} / \mathrm{v})$ polyacrylamide gels with a denaturing gradient of 15 to $55 \%$ for $16 \mathrm{~S}$ rRNA (total bacteria) and $16 \mathrm{~S}$ rRNA (AOB) and 20 to $70 \%$ for nifH (where $100 \%$ denaturation was achieved with $7 \mathrm{M}$ urea and $40 \%$ formamide). The gels were electrophoresed for 3 hours at $200 \mathrm{~V}$ and $60^{\circ} \mathrm{C}$. After electrophoresis, the gels were stained with SYBR Gold (Invitrogen, Breda, The Netherlands) in $0.5 \mathrm{x}$ TAE (Tris, acetate, EDTA) in the dark for 40 minutes and photographed under ultraviolet light using an E-BOX VX2 UV transilluminator.

The gels were analysed using the GelAnalyzer 2010 program. The structural similarity of the total, nitrogenfixing and ammonium-oxidizing bacterial communities was determined based on the presence or absence of amplicons detected after DGGE. The matrices were generated using the Bray-Curtis similarity index, and multidimensional scaling (MDS) analyses were performed with the 'Primer 6' program (Plymouth Marine, Primer, UK); differences among the treatments were assessed by similarity analysis (ANOSIM).

The total bacterial abundance and the abundance of $\mathrm{AOB}$ and diazotrophic bacteria were quantified by qPCR using 16S rRNA (total bacteria and AOB) and the nifH gene, respectively. The primers and reaction conditions are shown in Table 1. A negative control was added in all quantifications for the monitoring of contamination.

The reactions were performed in triplicate in a final volume of $10 \mu \mathrm{L}$ containing $5 \mu \mathrm{L}$ of the $\mathrm{GoTaq}^{\circledR}$ qPCR Master Mix (Promega, USA), $10 \mu \mathrm{M}$ of primers and 1 $\mu \mathrm{L}$ of DNA using a LightCycler ${ }^{\circledR} 480$ (Roche Applied Science). Standard curves were obtained using serial dilutions $\left(10^{-1}\right.$ to $\left.10^{-5}\right)$ of metagenomic DNA samples with known concentrations. All amplification reactions showed efficiency values between 94 and $100 \%$, and the $\mathrm{R}^{2}$ values of the standard curves were always higher than 0.98 . The results were submitted to analysis of variance, and the averages were compared by the Tukey test at $5 \%$ probability using the software Sisvar 5.6.

\section{RESULTS AND DISCUSSION}

The soils in all treatments presented a clayloamy texture, with the sand content varying from
49.6 to $66.0 \%$, silt ranging from 13.2 to $18.7 \%$ and clay ranging from 17.4 to $33.2 \%$. The soils showed significantly different $\mathrm{pH}$ values $(\mathrm{p}<0.05)$, where the intercropping management treatments showed more acidic $\mathrm{pH}$ values (5.26 in $\mathrm{B}+\mathrm{S}$ ). The other attributes did not present significant differences between treatments. Soils presented higher acidity as well as higher levels of $\mathrm{Al}^{3+}$ and $\mathrm{H}+\mathrm{Al}$ in the $\mathrm{B}+\mathrm{G}$ and $\mathrm{B}+\mathrm{S}$ treatments. The highest levels of calcium $\left(\mathrm{Ca}^{2+}\right)$, organic carbon $(\mathrm{CO})$ and total nitrogen (N-total) were observed in the $\mathrm{B}+\mathrm{G}$ and $\mathrm{B}+\mathrm{S}$ treatments, while the highest $\mathrm{NH}_{4}^{+}$levels were observed in the B treatment (Table 2).

Silva et al. (2013) also reported a higher acidity of soil under Gliricidia and Sabia cultivation compared to Brachiaria cultivation, attributing this acidity to a greater release of $\mathrm{H}^{+}$by legumes to balance the loads between soil and root due to higher cation uptake. The difference in $\mathrm{pH}$ between intercropping management treatments can also be attributed to the lower nitrifier activity in soils under Brachiaria-only treatment (Bowatte et al., 2011) due to the nitrification process that generates $\mathrm{H}^{+}$in the soil (Heil; Vereecken; Brüggemann, 2015), corroborating the higher levels of $\mathrm{NH}_{4}^{+}$and lower abundance of $\mathrm{AOB}$ in $\mathrm{B}$.

The communities of total bacteria, ammoniumoxidizing bacteria (AOB) and diazotrophic bacteria (nifH) were evaluated for their structure and diversity based on the DGGE profiles generated from the different samples. The MDS analyses of total bacteria and AOB formed two groups: one-group samples from the intercropping management treatments and another group of Brachiaria-only samples (Figure 1a and 1b). There was no formation of well-defined groups among the treatments in the analysis of diazotrophic bacteria (Figure 1c).

ANOSIM showed that the community structure of total bacteria and AOB was clearly different between the intercropping tree legume treatments and Brachiaria-only treatment (Table 3). This difference was related to the presence of legumes, which modified the soil chemical attributes, especially those related to acidity (Jesus et al., 2009).

Recent studies have demonstrated the correlation of the diversity of the total bacterial and $\mathrm{AOB}$ communities with the $\mathrm{pH}$ (chemical attributes) of the soil (Jeanbille et al., 2015; Nicol et al., 2008). Soil acidity acts directly on the structure and abundance of microbial communities because most bacterial taxa present tolerance to a narrow $\mathrm{pH}$ range for their growth (Rousk et al., 2010). 
Table 2: Physical and chemical attributes of soils under a silvopastoral system.

\begin{tabular}{|c|c|c|c|}
\hline & & Treatments & \\
\hline Physical attributes & $B$ & $B+G$ & $\mathrm{~B}+\mathrm{S}$ \\
\hline Sand $\left(\mathrm{g} \mathrm{kg}^{-1}\right)^{1}$ & $575 \pm 25$ & $524 \pm 8$ & $549 \pm 4$ \\
\hline Silt $\left(\mathrm{g} \mathrm{kg}^{-1}\right)^{1}$ & $165 \pm 5$ & $155 \pm 10$ & $140 \pm 1$ \\
\hline Clay $\left(\mathrm{g} \mathrm{kg}^{-1}\right)^{1}$ & $259 \pm 26$ & $321 \pm 3$ & $311 \pm 4$ \\
\hline Textural class & & Clay-loamy & \\
\hline \multicolumn{4}{|l|}{ Chemical attributes } \\
\hline $\mathrm{pH}\left(\mathrm{H}_{2} \mathrm{O}\right)^{2}$ & $5.74 \pm 0.02^{\mathrm{a}}$ & $5.42 \pm 0.06^{\mathrm{ab}}$ & $5.26 \pm 0.03^{b}$ \\
\hline$P\left(\mathrm{mg} \mathrm{kg}^{-1}\right)^{3}$ & $13.35 \pm 1.47$ & $10.23 \pm 1.12$ & $12.84 \pm 0.62$ \\
\hline $\mathrm{NH}_{4}^{+}\left(\mathrm{mg} \mathrm{kg}^{-1}\right)^{4}$ & $50.03 \pm 3.06$ & $30.02 \pm 3.47$ & $32.02 \pm 3.06$ \\
\hline $\mathrm{NO}_{3}^{-}\left(\mathrm{mg} \mathrm{kg}^{-1}\right)^{4}$ & $25.68 \pm 3.75$ & $25.85 \pm 3.45$ & $25.78 \pm 3.42$ \\
\hline$N_{\text {total }}\left(\mathrm{g} \mathrm{kg}^{-1}\right)^{7}$ & $2.25 \pm 0.14$ & $2.58 \pm 0.13$ & $2.72 \pm 0.09$ \\
\hline $\mathrm{CO}\left(\mathrm{g} \mathrm{kg}^{-1}\right)^{6}$ & $29.91 \pm 2.09$ & $30.01 \pm 0.84$ & $31.57 \pm 0.88$ \\
\hline $\mathrm{C} / \mathrm{N}$ & $13.26 \pm 0.09$ & $11.73 \pm 0.48$ & $11.66 \pm 0.39$ \\
\hline $\mathrm{Ca}^{2+}\left(\mathrm{cmolc} \mathrm{kg}^{-1}\right)^{4}$ & $2.84 \pm 0.15$ & $3.43 \pm 0.12$ & $2.90 \pm 0.14$ \\
\hline $\mathrm{Mg}^{2+}\left(\mathrm{cmolc} \mathrm{kg}^{-1}\right)^{4}$ & $0.55 \pm 0.06$ & $0.50 \pm 0.04$ & $0.68 \pm 0.02$ \\
\hline $\mathrm{K}^{+}\left(\mathrm{cmolc} \mathrm{kg}^{-1}\right)^{3}$ & $0.32 \pm 0.05$ & $0.23 \pm 0.03$ & $0.13 \pm 0.01$ \\
\hline $\mathrm{Na}^{+}\left(\mathrm{cmolc} \mathrm{kg}^{-1}\right)^{3}$ & $0.04 \pm 0.00$ & $0.06 \pm 0.01$ & $0.04 \pm 0.01$ \\
\hline $\mathrm{Al}^{3+}\left(\mathrm{cmolc} \mathrm{kg}^{-1}\right)^{4}$ & $0.20 \pm 0.00$ & $0.47 \pm 0.09$ & $0.50 \pm 0.04$ \\
\hline $\mathrm{H}+\mathrm{Al}\left(\mathrm{cmolc} \mathrm{kg}^{-1}\right)^{5}$ & $5.58 \pm 0.25$ & $6.48 \pm 0.34$ & $6.87 \pm 0.35$ \\
\hline SB (cmolc kg-1) & $3.75 \pm 0.23$ & $4.22 \pm 0.17$ & $3.75 \pm 0.16$ \\
\hline $\mathrm{T}\left(\mathrm{cmolc} \mathrm{kg}^{-1}\right)$ & $9.34 \pm 0.49$ & $10.70 \pm 0.21$ & $10.62 \pm 0.49$ \\
\hline $\mathrm{t}\left(\mathrm{cmolc} \mathrm{kg}^{-1}\right)$ & $3.95 \pm 0.23$ & $4.69 \pm 0.10$ & $4.25 \pm 0.14$ \\
\hline V $(\%)$ & $40.06 \pm 0.52$ & $39.64 \pm 2.23$ & $35.40 \pm 0.52$ \\
\hline m (\%) & $5.18 \pm 0.34$ & $10.13 \pm 2.08$ & $11.89 \pm 1.25$ \\
\hline
\end{tabular}

Means followed by the default error value; $n=3$. Means followed by different letters in the same line differ from each other at the $5 \%$ level by the Tukey test. ${ }^{1}$ Densimeter method (Almeida et al., 2012). ${ }^{2} 1: 2.5 ;{ }^{3}$ Mehlich $1 ;{ }^{4} \mathrm{KCl} 1 \mathrm{~mol} \mathrm{~L}^{-1} ;{ }^{5} \mathrm{Calcium}$ acetate at $\mathrm{pH} 7.0 ;{ }^{6}$ Potassium dichromate (EMBRAPA, 2009). ${ }^{7}$ Kjeldahl by steam distillation (EMBRAPA, 2011). CO: total organic carbon; SB: sum of bases; T: potential CTC; t: effective CTC; V: base saturation; m: aluminium saturation; B: Brachiaria only; B+S: Brachiaria intercropped with Sabia; B+G: Brachiaria intercropped with Gliricidia.

Cubillos et al. (2016) also observed significant differences in the structures of the total bacterial and AOB communities between soils under silvopastoral (with legumes Prosopis juliflora) and single-crop pastures. Bacterial communities can be stimulated by higher enzymatic activity and higher concentrations of $\mathrm{C}$ and $\mathrm{N}$ below the canopy of the trees, forming "islands of microbial communities" (Cubilos et al., 2016). Considering that most soil bacteria are heterotrophic, changes in the amount and quality of substrate available in the soil alter the structure and abundance of their communities, favouring copiotrophic bacteria in soils with high nutrient contents while disadvantaging oligotrophic bacteria (Leff et al., 2015).

We anticipated that the introduction of Gliricidia and sabia in the pasture could modify the structure of diazotrophic bacterial communities in relation to planting with Brachiaria alone because these legumes are able to associate with symbiotic diazotrophic bacteria (Coelho et al., 2018; Martins et al., 2015). Instead, we observed a great dispersion of the samples in the intercropping treatments in relation to the nifH gene, which could be associated with the free-living and associative diazotrophic diversity in the silvopastoral system (Gupta et al., 2014). 


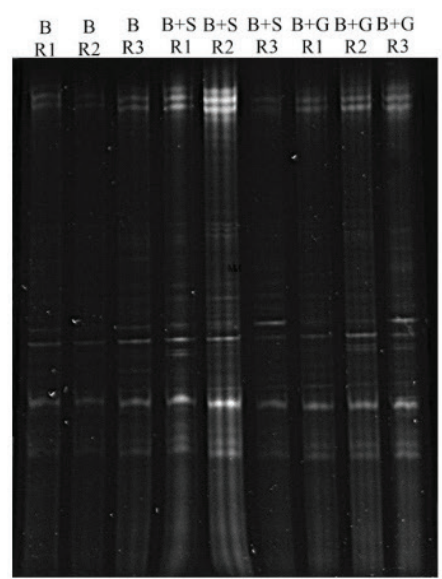

(a)

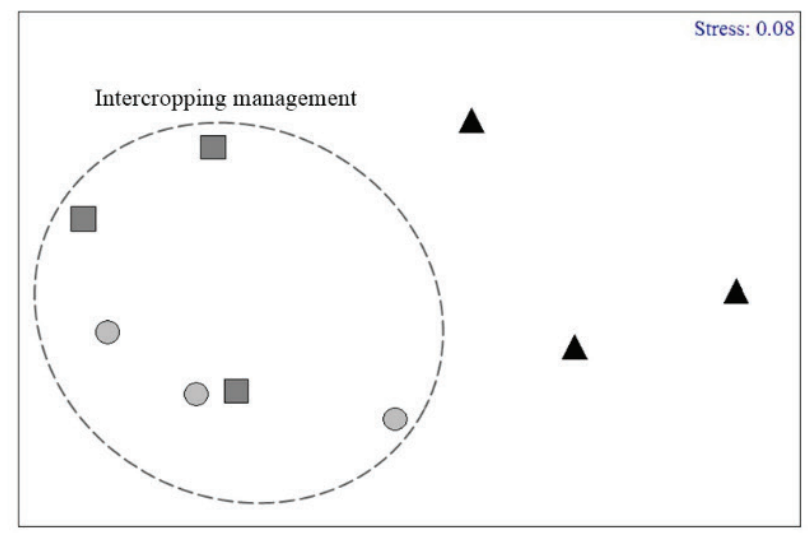

$\begin{array}{ccccccccc}\mathrm{B} & \mathrm{B} & \mathrm{B} & \mathrm{B}+\mathrm{S} & \mathrm{B}+\mathrm{S} & \mathrm{B}+\mathrm{S} & \mathrm{B}+\mathrm{G} & \mathrm{B}+\mathrm{G} & \mathrm{B}+\mathrm{G} \\ \mathrm{R} 1 & \mathrm{R} 2 & \mathrm{R} 3 & \mathrm{R} 1 & \mathrm{R} 2 & \mathrm{R} 3 & \mathrm{R} 1 & \mathrm{R} 2 & \mathrm{R} 3\end{array}$

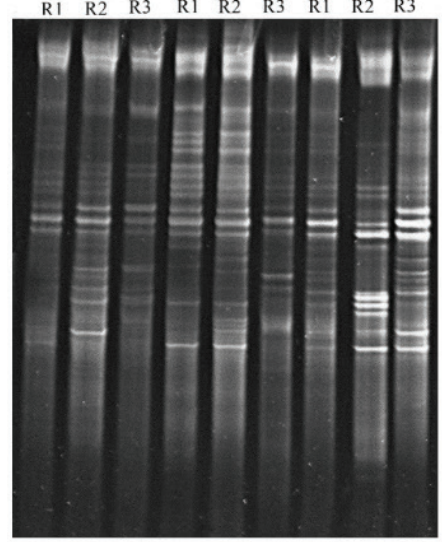

(b)

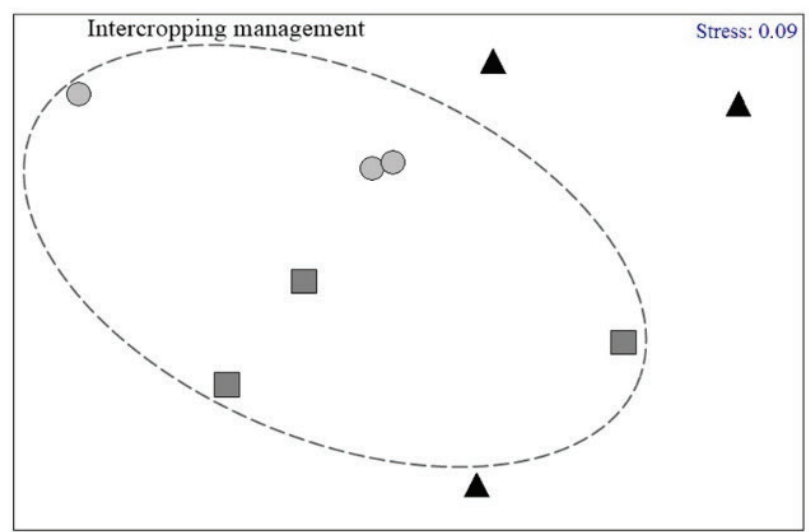

$\begin{array}{ccccccccc}\mathrm{B} & \mathrm{B} & \mathrm{B} & \mathrm{B}+\mathrm{S} & \mathrm{B}+\mathrm{S} & \mathrm{B}+\mathrm{S} & \mathrm{B}+\mathrm{G} & \mathrm{B}+\mathrm{G} & \mathrm{B}+\mathrm{G} \\ \mathrm{R} 1 & \mathrm{R} 2 & \mathrm{R} 3 & \mathrm{R} 1 & \mathrm{R} 2 & \mathrm{R} 3 & \mathrm{R} 1 & \mathrm{R} 2 & \mathrm{R} 3\end{array}$

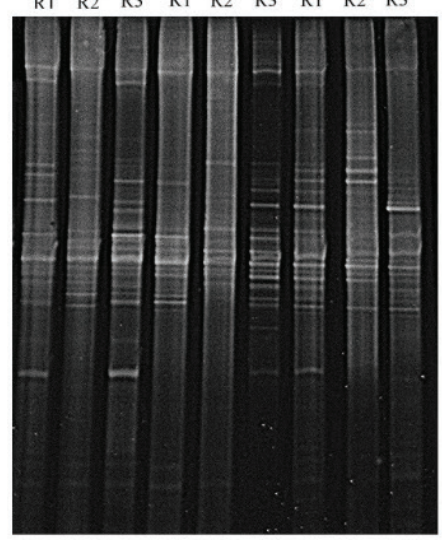

(c)

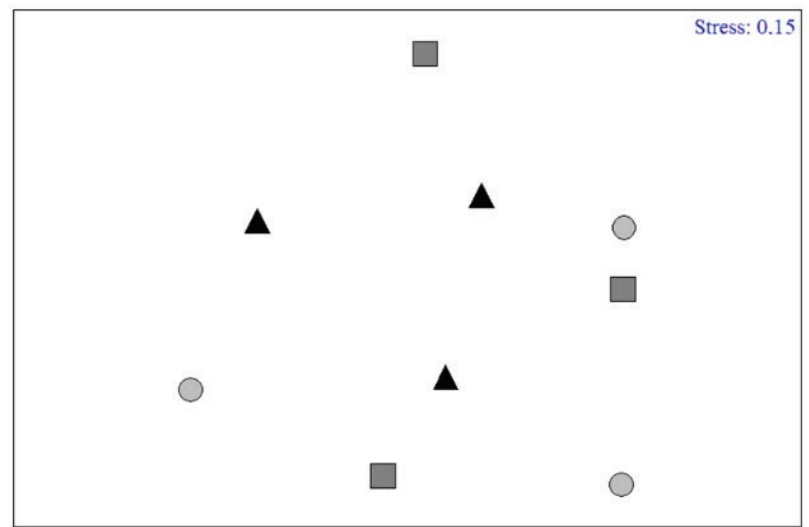

A Brachiaria only

Brachiaria intercropped with Gliricidia

Brachiaria intercropped with Sabia

Figure 1: Amplicon profiles and multidimensional scaling (MDS) results of the $16 \mathrm{~S}$ rRNA total bacterial gene (a), the 16S rRNA gene of ammonium-oxidizing bacteria (AOB) (b) and the nifH gene of diazotrophic bacteria (c) in soils of a silvopastoral system. B: $\Delta$ Brachiaria only; B+G: Brachiaria intercropped with Gliricidia; B+S: Brachiaria intercropped with Sabia; R: repetitions. 
Table 3: R statistic values of the similarity analysispairing test based on the DGGE profiles of the 16S rRNA genes from total bacteria and ammoniumoxidizing bacteria (AOB) and of the nifH gene from diazotrophic bacteria in soils of a silvopastoral system.

\begin{tabular}{cccc}
\hline Treatments & Bacteria & AOB & nifH \\
\hline \multicolumn{3}{c}{ R Statistic } \\
\hline $\mathrm{B} \times \mathrm{B}+\mathrm{G}$ & $0.81^{*}$ & $0.61^{*}$ & $0.24^{\text {ns }}$ \\
$\mathrm{B} \times \mathrm{B}+\mathrm{S}$ & $0.79^{*}$ & $0.48^{*}$ & $0.14^{\text {ns }}$ \\
$\mathrm{B}+\mathrm{G} \times \mathrm{B}+\mathrm{S}$ & $0.07^{\text {ns }}$ & $0.18^{\text {ns }}$ & $0.03^{\text {ns }}$ \\
\hline
\end{tabular}

*Significant at 10\%; ns not significant. R>0.75: well-separated groups; R>0.5: groups with overlap but clearly differentiated; $\mathrm{R}<0.25$ : not well-separated groups. B: Brachiaria only; $\mathrm{B}+\mathrm{S}$ : Brachiaria intercropped with Sabia; $\mathrm{B}+\mathrm{G}$ : Brachiaria intercropped with Gliricidia.

The abundance of total bacteria, AOB and diazotrophic bacteria was evaluated by qPCR. All standard curves showed $\mathrm{R}^{2}$ values greater than 0.99 , and the amplification efficiency was always above $90 \%(16 \mathrm{~S}$ rRNA: $\mathrm{R}^{2}=0.997, \mathrm{Eff}=94.7 \%$; $16 \mathrm{~S}$ rRNA of AOB: $\mathrm{R}^{2}$ $=0.995, \mathrm{Eff}=100 \% ;$ nifH: $\mathrm{R}^{2}=0.995$, Eff $=97.75 \%$ ). The greatest abundance was observed in intercropping treatments, with $\mathrm{B}+\mathrm{G}$ showing a higher number of copies and with significant differences only for the nifH gene abundance (Figure 2).
The highest copy numbers of total bacteria in soils planted with legumes were due to the deposition of organic compounds via exudates and to the capacity to alter soil physical attributes (such as the porosity, humidity and temperature), resulting in microhabitats for bacteria (Moura et al., 2015; Wang et al., 2015). Despite the influence of $\mathrm{N}$ availability on the abundance of nitrifying communities (Chen et al., 2006; Meyer et al., 2013), we attributed the lower abundance of AOB in $\mathrm{B}$ to the exudation of nitrification inhibitors by the Brachiaria species. Pastures of Brachiaria species are known to exude complex organic compounds, such as methylated phenolic acids and terpenes, blocking the ammonium monooxygenase enzyme, reducing nitrification (Subbarao et al., 2009; Gopalakrishnan et al., 2007) and supplying energy for $\mathrm{CO}_{2}$ fixation by AOB.

The highest copy numbers of the nif $\mathrm{H}$ gene in $\mathrm{B}+\mathrm{G}$ and $\mathrm{B}+\mathrm{S}$ are related to the excretion of chemical signalling compounds by legumes, stimulating the action of N-fixing bacteria (Janczarek et al., 2015). The greater number of nifH gene copies in leguminous soils may also be associated with greater carbon availability from tree crowns because the availability of carbohydrates is important got BNF activity, which requires large amounts of energy (Huhe et al., 2014). Moreover, the high availability of $\mathrm{NH}_{4}^{+}$in treatment $\mathrm{B}$ soils may have suppressed the activity of diazotrophic in this treatment (Orr et al., 2011), resulting in lower abundance. (a)

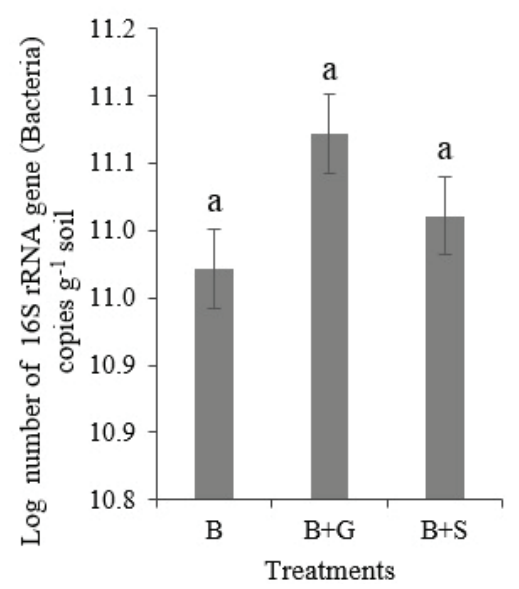

(b)

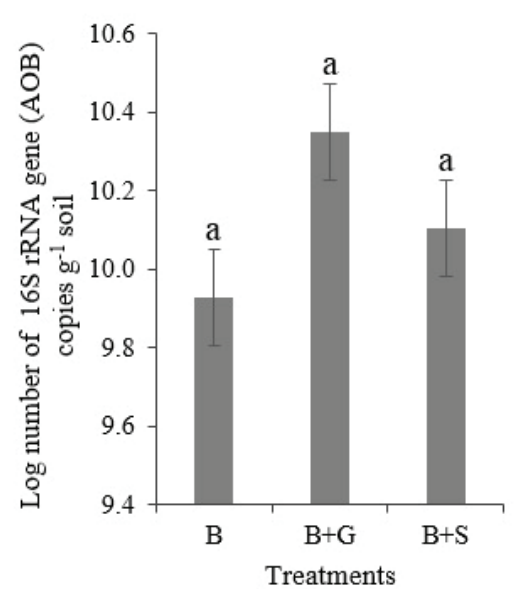

(c)

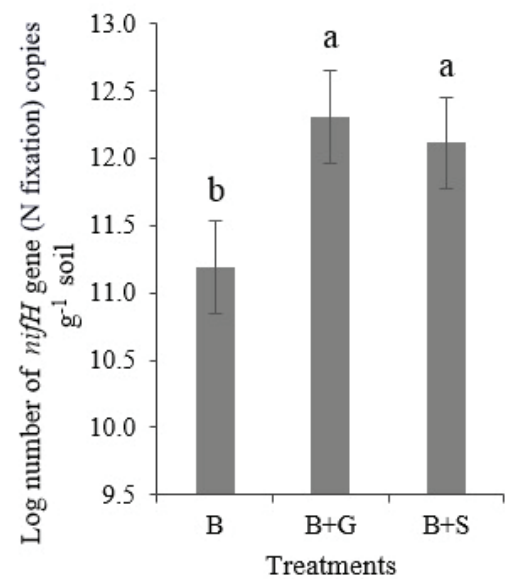

Figure 2: Copy numbers of the 16S rRNA gene (total bacteria) (a), copy numbers of the 16S rRNA gene of ammonium-oxidizing bacteria (AOB) (b) and copy numbers of the nifH gene of diazotrophic bacteria (c) in soils of a silvopastoral system. Mean copy numbers were log transformed. Error bars represent the standard error $(n=3)$. Bars labelled with the same letter in each graph do not differ statistically according to Tukey's test ( $p<0.05$ ). B: Brachiaria only; B+S: Brachiaria intercropped with Sabia; B+G: Brachiaria intercropped with Gliricidia. 


\section{CONCLUSIONS}

Intercropping tree legumes with forage grasses in silvopastoral systems improves the biological quality of the soil. The introduction of Gliricidia and sabia to soils planted with a Brachiaria species changed the community structure of the total bacteria and ammonium-oxidizing bacteria in the soil, possibly through the chemical attributes of the soil, without affecting the community structure of $\mathrm{N}$-fixing bacteria (diazotrophic bacteria). Intercropping tree legumes with Brachiaria species promotes the growth number of total bacteria, AOB and N-fixing bacteria in the soil to provide better conditions for microbial growth compared to planting with Brachiaria species alone.

\section{ACKNOWLEDGMENTS}

Conselho Nacional de Desenvolvimento Científico e Tecnológico (CNPq, Brasília, Brazil) for the financial support, the Instituto Agronômico de Pernambuco (IPA, Pernambuco, Brazil) for the experimental facilities and Dr. Herbert Álvaro Abreu de Siqueira from the Patologia de Insetos Laboratory (UFRPE, Pernambuco, Brazil) for qPCR analyses.

\section{REFERENCES}

ALMEIDA, B. G. et al. Padronização de métodos para análise granulométrica no Brasil. Embrapa Solos-Comunicado Técnico (INFOTECA-E), 2012. 11 p.

APOLINÁRIO, V. X. O. et al. Decomposition of arboreal legume fractions in a silvopastoral System. Crop Science, 56(3):1356-1363, 2016.

APOLINÁRIO, V. X. O. et al. Tree legumes provide marketable wood and add nitrogen in warm-climate silvopasture systems. Agronomy Journal, 107(5):19151921, 2015.

ASHWORTH, A. J.; WEST, C. P. Biologically fixed nitrogen in legume intercropped systems: Comparison of nitrogendifference and nitrogen-15 enrichment techniques. Agronomy Journal, 107(6):2419-2430, 2015.

BOLLMANN, A.; BULLERJAHN, G. S.; MCKAY, R. M. Abundance and diversity of ammonia-oxidizing archaea and bacteria in sediments of trophic end members of the laurentian great lakes, erie and superior. PLoS ONE, 9(5):e97068, 2014.

BOWATTE, S. et al. Effect of grass species and fungal endophyte on soil nitrification potential. New Zealand Journal of Agricultural Research, 54(4):275-284, 2011.
CANFIELD, D. E.; GLAZER, A. N.; FALKOWSKI, P. G. The evolution and future of earth's nitrogen cycle. Science, 330(6001):192-196, 2010.

CHEN, Z. et al. Change in the abundance and community composition of ammonia-oxidizing bacteria and archaea at soil aggregate level as native pasture converted to cropland in a semiarid alpine steppe of central Asia. Journal of Soils and Sediments, 16(1):243-254, 2016.

COELHO, K. P. et al. Symbiosis of rhizobia with Gliricidia sepium and Clitoria fairchildiana in an Oxisol in the pre-Amazon region of Maranhão State. Acta Scientiarum: Agronomy, 40(1)e35248, 2018.

COMPANHIA PERNAMBUCANA RECURSOS HÍDRICOS - CPRH. Diagnóstico sócio ambiental do Litoral Norte de Pernambuco. Recife, 2003. 214p.

CUBILLOS, A. M. et al. Effect of the conversion of conventional pasture to intensive silvopastoral systems on edaphic bacterial and ammonia oxidizer communities in Colombia. European Journal of Soil Biology, 72:42-50, 2016.

DIAS, A. C. F. et al. Potato cultivar type affects the structure of ammonia oxidizer communities in field soil under potato beyond the rhizosphere. Soil Biology \& Biochemistry, 50:85-95, 2012.

DING, G. C. et al. Changes of soil bacterial diversity as a consequence of agricultural land use in a semi-arid ecosystem. PLoS ONE, 8(3):e59497, 2013.

EMPRESA BRASILEIRA DE PESQUISA AGROPECUÁRIA EMBRAPA. Manual de análises químicas de solos, plantas e fertilizantes. Embrapa Informação Tecnológica; Rio de Janeiro: Embrapa Solos, 2009. 627p.

EMPRESA BRASILEIRA DE PESQUISA AGROPECUÁRIA EMBRAPA. Manual de métodos de análise de solo. Embrapa Solos-Documentos (INFOTECA-E), 2011. 230p.

FRACETTO, F. J. C. et al. Effect of agricultural management on $\mathrm{N}_{2} \mathrm{O}$ emissions in the Brazilian sugarcane yield. Soil Biology and Biochemistry, 109:205-213, 2017.

GABY, J. C.; BUCKLEY, D. H. A comprehensive evaluation of PCR primers to amplify the nifh gene of nitrogenase. PLoS one, 7(7):e42149, 2012.

GOPALAKRISHNAN, S. et al. Nitrification inhibitors from the root tissues of Brachiaria humidicola, a tropical grass. Journal of Agricultural and Food Chemistry, 55(4):13851388, 2007. 
GUPTA, V. V. S. R. et al. Nitrogen cycling in summer active perennial grass systems in South Australia: Non-symbiotic nitrogen fixation. Crop and Pasture Science, 65(10):10441056, 2014.

HEIL, J.; VEREECKEN, H.; BRÜGGEMANN, N. A review of chemical reactions of nitrification intermediates and their role in nitrogen cycling and nitrogen trace gas formation in soil. European journal of soil Science, 67(1):23-39, 2016.

HERRIDGE, D. F.; PEOPLES, M. B.; BODDEY, R. M. Global inputs of biological nitrogen fixation in agricultural systems. Plant and Soil, 311(1):1-18, 2008.

HERMANSSON, A.; LINDGREN, P. E. Quantification of ammoniaoxidizing bacteria in arable soil by real-time PCR. Applied and Environmental Microbiology, 67(2):972-976, 2001.

HILL, G. T. et al. Methods for assessing the composition and diversity of soil microbial communities. Applied Soil Ecology, 15(1):25-36, 2000.

HUHE, S. B. et al. Effect of abandonment on diversity and abundance of free-living nitrogen-fixing bacteria and total bacteria in the cropland soils of Hulun Buir, Inner Mongolia. PloS one, 9(9):e106714, 2014.

INSTITUTO AGRONÔMICO DE PERNAMBUCO - IPA. Banco de dados agrometeorológicos. Recife: 1994.100p.

IPATA, P. L.; PESI, R. What is the true nitrogenase reaction? A guided approach. Biochemistry and Molecular Biology Education, 42(3):142-144, 2015.

JANCZAREK, M. et al. Signal molecules and cell-surface components involved in early stages of the legumerhizobium interactions. Applied Soil Ecology, 85:94-113, 2015.

JEANBILLE, M. et al. Soil parameters drive the structure, diversity and metabolic potentials of the bacterial communities across temperate beech forest soil sequences. Microbial Ecology, 71(2):482-493, 2016.

JESUS, E. C. et al. Changes in land use alter the structure of bacterial communities in Western Amazon soils. ISME Journal, 3(9):1004-1011, 2009.

KEUTER, A.; VELDKAMP, E.; CORRE, M. D. Asymbiotic biological nitrogen fixation in a temperate grassland as affected by management practices. Soil Biology \& Biochemistry, 70: 38-46, 2014.

KOWALCHUK, G. A. et al. Analysis of ammonia-oxidizing bacteria of the beta subdivision of the class Proteobacteria in coastal sand dunes by denaturing gradient gel electrophoresis and sequencing of PCR-amplified $16 \mathrm{~S}$ ribosomal DNA fragments. Applied and Environmental Microbiology, 63(4):1489-1497, 1997.

KOWALCHUK, G. A.; STEPHEN, J. R. Ammonia-Oxidizing Bacteria: A model for molecular microbial ecology. Annual Reviews in Microbiology, 55: 485-529, 2001.

KURAMAE, E. E. et al. Soil characteristics more strongly influence soil bacterial communities than land-use type. FEMS Microbiology Ecology, 79(1):12-24, 2012.

LEFF, J. W. et al. Consistent responses of soil microbial communities to elevated nutrient inputs in grasslands across the globe. Proceedings of the National Academy of Sciences, 112(35):10967-10972, 2015.

LEVY-BOOTH, D. J.; PRESCOTT, C. E.; GRAYSTON, S. J. Microbial functional genes involved in nitrogen fixation, nitrification and denitrification in forest ecosystems. Soil Biology \& Biochemistry, 75:11-25, 2014.

LIMA-PERIM, J. E. et al. Linking the composition of bacterial and archaeal communities to characteristics of soil and flora composition in the Atlantic Rainforest. PLoS one, 11(1):e0146566, 2016.

MARTINS, P. G. S. et al. Mimosa caesalpiniifolia rhizobial isolates from different origins of the Brazilian Northeast. Archives of Microbiology, 197(3):459-469, 2015.

MENDES, L. W. et al. Soil-borne microbiome: Linking diversity to function. Microbial Ecology, 70(1):255-265, 2015.

MEYER, A. et al. Different land use intensities in grassland ecosystems drive ecology of microbial communities involved in nitrogen turnover in soil. PLoS ONE, 8(9):e73536, 2013.

MOURA, E. G. et al. Contribution of legume tree residues and macrofauna to the improvement of abiotic soil properties in the eastern Amazon. Applied Soil Ecology, 86:91-99, 2015.

MUYZER, G.; DEWAAL, E. C.; UITTERLINDEN, A. G. Profiling of complex microbial-populations by denaturing gradient gel-electrophoresis analysis of polymerase chain reactionamplified genes-coding for $16 \mathrm{~S}$ ribosomal-RNA. Applied and Environmental Microbiology, 59(3):695-700, 1993.

NANNIPIERI, P. et al. Microbial diversity and soil functions. European Journal of Soil Science, 68(1):12-26, 2017.

NICOL, G. W. et al. The influence of soil pH on the diversity, abundance and transcriptional activity of ammonia oxidizing archaea and bacteria. Environmental Microbiology, 10(11):2966-2978, 2008. 
ORR, C. H. et al. Diversity and activity of free-living nitrogen-fixing bacteria and total bacteria in organic and conventionally managed soils. Applied and Environmental Microbiology, 77(3):911-919, 2011.

PAJARES, S.; BOHANNAN, B. J. M. Ecology of nitrogen fixing, nitrifying, and denitrifying microorganisms in tropical forest soils. Frontiers in Microbiology, 7:1045, 2016.

PATWARDHAN, A.; RAY, S.; ROY, A. Molecular markers in phylogenetic studies. A review. Phylogenetics \& Evolutionary Biology, 2:100-131, 2014.

PAZ-FERREIRO, J.; FU, S. Biological indices for soil quality evaluation: perspectives and limitations. Land Degradation \& Development, 27(1):14-25, 2016.

POLY, F.; MONROZIER, L. J.; BALLY, R. Improvement in the RFLP procedure for studying the diversity of nifH genes in communities of nitrogen fixers in soil. Research in Microbiology, 152(1):95-103, 2001.

QU, T-b et al. Impacts of grazing intensity and plant community composition on soil bacterial community diversity in a steppe grassland. PloS one, 11(7):e0159680, 2016.

ROUSK, J. et al. Soil bacterial and fungal communities across a pH gradient in an arable soil. The ISME Jornal, 4(10):13401351, 2010.

RASHID, M. I. et al. Bacteria and fungi can contribute to nutrients bioavailability andaggregate formation in degraded soils. Microbiological Research, 183:26-41, 2016.

SILVA, A. B. et al. Estoque de serapilheira e fertilidade do solo em pastagem degradada de Brachiaria decumbens após implantação de leguminosas arbustivas e arbóreas forrageiras. Revista Brasileira de Ciência do Solo, 37(2):502-511, 2013.

SIMONET, P. et al. Frankia genus specific characterization by polymerase chain reaction. Applied and Environmental Microbiology, 57(11):3278-3286, 1991.
SPATZAL, T. et al. Nitrogenase FeMoco investigated by spatially resolved anomalous dispersion refinement. Nature Communications, 7: 2016.

SUBBARAO, G. V. et al. Evidence for biological nitrification inhibition in Brachiaria pastures. Proceedings of the National Academy of Sciences, 106(41):17302-17307, 2009.

SUGIYAMA, A. et al. Changes in the bacterial community of soybean rhizospheres during growth in the field. PLoS one, 9(6):e100709, 2014.

TOURNA, M. et al. Growth, activity and temperature responses of ammonia-oxidizing archaea and bacteria in soil microcosms. Applied and Environmental Microbiology, 10(4):1357-64, 2008.

URQUIAGA, S. et al. Evidence from field nitrogen balance and ${ }^{15} \mathrm{~N}$ natural abundance data for the contribution of biological $\mathrm{N}_{2}$ fixation to Brazilian sugarcane varieties. Plant and Soil, 356(1): 5-21, 2012.

WANG, F. et al. Planting increases the abundance and structure complexity of soil core functional genes relevant to carbon and nitrogen cycling. Scientific Reports, 5:2015.

WEIDNER, S. et al. Bacterial diversity amplifies nutrient-based plant-soil feedbacks. Functional Ecology, 29(10):13411349, 2015.

WURZBURGER, N. et al. Molybdenum and phosphorus interact to constrain asymbiotic nitrogen fixation in tropical forests. PLoS ONE, 7(3):e33710, 2012.

XAVIER, D. F. et al. Dinâmica da serapilheira em pastagens de braquiária em sistema silvipastoril e monocultura. Pesquisa Agropecuária Brasileira, 46(10):1214-1219, 2011.

YEOH, Y. K. et al. The core root microbiome of sugarcanes cultivated under varying nitrogen fertilizer application. Environmental Microbiology, 18(5):1338-1351, 2016. 